DOI: $10.15393 /$ j10.art.2019.4341

УДК $821.161 .1+930.253$

\title{
А. В. Индзинская
}

Государственный соииально-гуманитарный университет (Коломна, Российская Федераиия)

annain76@mail.ru

\section{Ф. М. Достоевский в переписке Е. А. Штакеншнейдер с Я. П. Полонским}

Аннотация. Елена Андреевна Штакеншнейдер (1836-1897), мемуаристка и хозяйка литературно-художественного салона в Санкт-Петербурге в 1870 -х - начале 1880 -х гг., в течение 25 лет (1860-1885) вела записи о Ф. М. Достоевском и его творчестве. Она отмечала его публичные выступления, описывала внешность и привычки, давала критическую оценку произведениям и пыталась выявить особенности его художественного мира, никогда не сомневаясь в величине его дарования. В данной публикации проанализирована неизданная переписка Е. А. Штакеншнейдер с Я. П. Полонским, их общим с Достоевским близким знакомым, а также приведены ранее не публиковавшиеся фрагменты ее дневников. Это позволило уточнить некоторые факты биографии Ф. М. Достоевского и пополнить собрание прижизненных критических отзывов и свидетельств о его деятельности и творчестве. Кропотливая многолетняя собирательская и мемуарная работа Е. А. Штакеншнейдер, данный ею глубокий анализ дарования Достоевского, в подтексте которого проступает христианская аксиология, позволили сделать вывод об этой женщине как об одной из первых исследовательниц творчества писателя. Пример Е. А. Штакеншнейдер показывает, как, вопреки недоброжелательным оценкам критики, неуклонно возрастало количество сочувствующих его идеям людей, а в них крепло желание сохранить образ и наследие великого соотечественника для потомков.

Ключевые слова: Е. А. Штакеншнейдер, Ф. М. Достоевский, Я. П. Полонский, переписка, мемуары, литературная критика

Об авторе: Индзинская Анна Владимировна - кандидат филологических наук, ведущий научный сотрудник, ГОУ ВО МО «Государственный социально-гуманитарный университет» (ул. Зеленая, 30, г. Коломна, Московская обл., Российская Федерация, 140411)

Дата поступления: 18.09.2019

Дата публикации: 06.12.2019

Для цитирования: Индзинская А. В. Ф. М. Достоевский в переписке Е. А. Штакеншнейдер с Я. П. Полонским // Неизвестный Достоевский. - 2019. - № 4. - C. 139-158. DOI: 10.15393/j10.art.2019.4341

$\mathrm{T}$ ворчество Ф. М. Достоевского в прижизненной критике выглядело явлением удивительным: усиливающееся непонимание «жестокого таланта» со стороны «собратьев по литературе» ${ }^{1}$, доходящее до оскорбительных высказываний в печати, искупалось возрастающим признанием читателей и их искренней любовью. Лишь в самом конце жизни (и особенно в момент смерти) оценка критики и мнение «публики» совпали ненадолго в определении его наследия как национального достояния. И главная заслуга в том единении принадлежала бесконечно разнообразному читательскому хору современников, отдельные голоса которого оказались способными звучать через века, и ценность их свидетельств со временем только увеличивалась. 
Один из таких голосов, бесспорно, принадлежит мемуаристке Елене Андреевне Штакеншнейдер (1836-1897) - дочери придворного архитектора Андрея Ивановича Штакеншнейдера (1802-1865) и хозяйки литературнохудожественного салона Петербурга в 1855-1862 гг. Марии Федоровны Штакеншнейдер (1811-1892). В 1870-х - нач. 1880-х гг. Елена Андреевна возродила семейную традицию журфиксов, и среди ее знакомых оказалась семья Достоевских: «В 1873 году, - вспоминала А. Г. Достоевская, - Федор Михайлович возобновил старинное знакомство с семейством Штакеншнейдер, центром которого была Елена Андреевна, дочь знаменитого архитектора. Она была умна и литературно образована и соединяла у себя по воскресеньям общество литераторов и художников. Она была всегда чрезвычайно добра к Федору Михайловичу и ко мне, и мы очень сошлись» [Достоевская: 309]. В черновом варианте воспоминаний жена Достоевского к данной записи добавила: «На ея воскресеньяхъ я встрьчала Я. П. Полонскаго, Майкова, Страхова, Аверкіева, Случевскаго и многихъ другихъ»².

Е. А. Штакеншнейдер с детства страдала неизлечимым заболеванием суставов, которое не позволило ей создать семью, но развило чуткость души и обострило желание быть полезной: «Без таланта, без способностей, писала она 28 декабря 1861 г. (10 января 1862 г.) - не имея ничего, что бь могла я принести за жизнь и ее дар, какие бы они ни были, я даю труд мой. Я употреблю все мои старания, все умственные силь, чтоб выразить, чтоб передать то, что передано мне, все, что я приняла из книг, или живым словом, или наблюдением» ${ }^{3}$. Дневниковые записи, которые Штакеншнейдер вела с 1854 г. в течение трех десятилетий оказались не только образцами лучшей отечественной мемуарной прозы второй половины XIX в., но и ценным источником для историков литературы: одним из увлечений мемуаристки стало создание «портретов» современников. Неизданная переписка Е. А. Штакеншнейдер с Я. П. Полонским, а также ранее не публиковавшиеся фрагменты ее дневников позволили уточнить факты биографии Ф. М. Достоевского и, что не менее важно, пополнить собрание прижизненных критических отзывов и свидетельств о его деятельности и творчестве.

\section{$x * *$}

Известные на сегодня записи о Ф. М. Достоевском, принадлежащие Е. А. Штакеншнейдер, охватывают четверть века - с 1860 по 1885 гг. И первые из них связаны с началом общественно-литературной деятельности писателя после возвращения в Петербург ${ }^{4}-$ с публичными чтениями, на которых мемуаристка имела возможность присутствовать лично, и изданием журнала.

8 января 1861 г. вышел первый номер «Времени», в котором Ф. М. Достоевский был соредактором брата М. М. Достоевского. Успех издания у читателей и критиков, по признанию писателя, был ему «дороже всего» ${ }^{5}$ и должен был определить направление его дальнейших творческих усилий - в итоге для литературного отдела за год с небольшим был написан роман «Униженные и оскорбленные» 6 . 
Поэтому переживания по поводу нового романа стали лейтмотивом эпистолярия Достоевского 1861 г.

Одним из адресатов писателя этого периода оказался Я. П. Полонский: он был приглашен к участию в литературном отделе и начал писать для «Времени» роман в стихах «Свежее преданье», который, как и роман «Униженные и оскорбленные», выходил частями ${ }^{8}$. Достоевский смотрел в то время на поэтическое дарование Полонского как на «несомненный факт нашей литературы, утвердившийся помимо критики; как на блестящее имя - созданное силой одного таланта и силой сочувствия читающей массы» ${ }^{9}$ Однако полноценным сотрудником «Времени», несмотря на желание редакции, Полонский так и не стал: с первых дней лета 1861 г. он уехал за границу, в Европу, а там работать почти не мог.

Задушевным адресатом Полонского к концу 1850-х гг. стала Е. А. Штакеншнейдер ${ }^{10}$, переписка с которой была поэту большим утешением в постигшем его несчастье и череде болезней ${ }^{11}$. Дружеское знакомство с семьей Штакеншнейдеров, и особенно с Е. А. Штакеншнейдер, поддерживалось Полонским до конца жизни ${ }^{12}$. В частности, оно выразилось в шутливых обращениях «дядя» И «тетка», которыми обменивались адресаты в течение десятилетий ${ }^{13}$.

О плане предстоящего путешествия Полонский сообщил ей 23 мая 1861 г. и в том же письме упомянул Достоевских («Вчера не могъ быть и на именинахъ $M^{\underline{m e}}$ Достоевской гдю обющаль быть непремпнно» $\left.{ }^{14}\right)$, с которыми, как и со Штакеншнейдерами, был дружен.

Нужно пояснить, что Ф. М. Достоевский весной 1861 г. еще не был посетителем литературного салона Марии Федоровны Штакеншнейдер и лично Елену Андреевну не знал (см. ниже письмо Полонского к Штакеншнейдер от 7 августа 1861 г., где он пишет, что послал Достоевскому мнение Елены Андреевны о романе «Униженные и оскорбленные», назвав ее «одной ему неизвъстной петербуржской дъвушкой»). Это не мешало Полонскому упоминать Достоевского как своего близкого знакомого, а девушке отмечать в дневнике факты его публичных выступлений, рассуждать о страдании «за правду» на каторге и с удивлением наблюдать петербургскую публику, которая - в присутствии Достоевского - принимала с овациями поэта Т. Г. Шевченко ${ }^{15}$. Традиция упоминания имени Достоевского сохранялась в их переписке до конца жизни.

О финансовой подоплеке своего отъезда в первых числах июня, бедственном положении и участии Достоевского Полонский написал Штакеншнейдер почти через две недели после отъезда - 12 июня 1861 г.:

«Денегъ у меня на всё бы хватило, если быя быль здоровъ и оставался на мпстпь. Яудраль за гранииу съ баснословно маленькой суммой - а именно съ 270 рублями и еще теперь остается до 300 гульденовъ (т. е. полтинникъ), и это мнть было бы очень довольно до полученія 300 руб. отъ Достоевскаго за романъ» ${ }^{16}$. 
Тем временем редакция «Времени» ждала от поэта продолжения «Свежего преданья». Желание читательского успеха произведению Полонского, отдавшему для издания в июне 1861 г. всего 3 главы, а также предчувствие неудачи собственного романа выразилось у Достоевского в письме от 31 июля 1861 г.:

«Весь романб, напечатанный цңпликомб, произвель-бы впечатлпніе гораздо сильнпиичее. $<\ldots>$. $Я<\ldots$.. очень плохо сдплаль что моихъ "Униженныхъ и Оскорбленныхъ" растянуль до Іюля, и ослабиль впечатлюніе. <...> Если вы въ этомг году напечатаете еще хоть только 3 главы, то иялльно и рельефно поставите ваче произведеніе передъ публикой» ${ }^{17}$.

Почти месяцем раньше Е. А. Штакеншнейдер в послании от 2 июля 1861 г. также подбадривала и хвалила своего унывающего «дядю», одновременно комментируя объявление о «Свежем предании» во «Времени» ${ }^{18}$ :

«Свтнее Преданье вышло на дняхъ, какъ я Вамъ пророчила въ одно время съ свижими огуриами, - что о немъ говорять, - сюда, въ нашу глушь ${ }^{19}$ не слышно, что говорю я, Ваша тетка, Вы знаете. Что Вы не знаете, это то, что отрывки изъ него выдумали вертет<ь>ся у меня на языкп не сходя съ мпста, такъ, что надогли. Еще, что Выможеть быть не знаете, это то, ито о романп Вашемъ, до появленія его въ свптп, прокричали, что онъ безподобенъ и то и сё. "Я Вашей славою и Вами, какъ нянька старая, горжусь" ${ }^{\prime 20}$, но въ то же время и сержусь: я помню, что мнг не понравилась Италія ${ }^{21}$, когда я ее увидпла въ первый разб оттого, что и о ней прокричали ${ }^{22}$. Каждый составляеть себю свое, по своему идеалу понятіе, встрпчаеть другое, и не доволенъ. Это ваши посльднніе Могикане, Достоевскіе

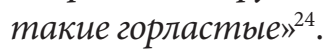

В том же письме Штакеншнейдер поместила характеристику романа «Униженные и оскорбленные», которая может считаться одной из ранних попыток указания на феномен творчества Достоевского:

«Вымель Конець четвертой части Униженныхъ и Оскорбленныхъ. Ну ужъ Яковъ Петровичь, оно увлекательно-то увлекательно, да такъ только странно, въ особенности встрпча Наташи съ Катей. Ну что это за Наташа, что это за Катя, такія прелести! Но скажите, по совпсти Вы, гуляя по свпту и загля-

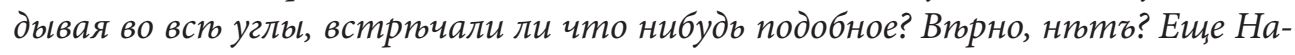
таша можеть быть, а Катя ужъ нютьг, да нють, да и Алеша нютьг.

Видь въ Достоевскомб, что дорого, это естественность неестественности, это обыденность разговора, слога. Онъ создаль самъ себи, не по образу Божію, а по своему собственному образу человпчковъ, и видить и мы всп видимб, что они

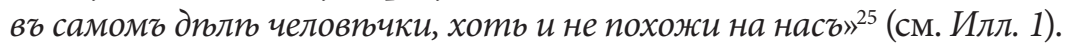

Читательский отзыв Штакеншнейдер был метафорически смелым и доброжелательно лаконичным. Он проницательно характеризовал художественный метод Достоевского, при котором доверие к написанному 
порождается и определяется манерой изложения вопреки необычайности событий и положений героев («что дорого, это естественность неестественности, это обыденность разговора, слога»). Интересно, что имплицитно отзыв содержал указание на то, что позже М. М. Бахтин назовет полифоническим типом художественного мышления: каждый герой романа обладал правом самостоятельного, наряду с авторским, голоса ${ }^{26}$, а значит, являл собой полноценный, человеческий образ («в самом деле человечки») (курсив мой. - A. И.). Была отмечена такая особенность творческого метода Достоевского, которая позволяет, по выражению Д. С. Лихачева, «ввести самого себя в действие» и усилить авторское «соучастие» в развитии событий («он создал сам себе», «по своему собственному образу») ${ }^{27}$. От наблюдательности «любезной тетки» не ускользнула и некоторая искусственность повествования, определенная свойством образной системы, состоящей, по прихотливой воле писателя, только из «человечков», а не из героев.

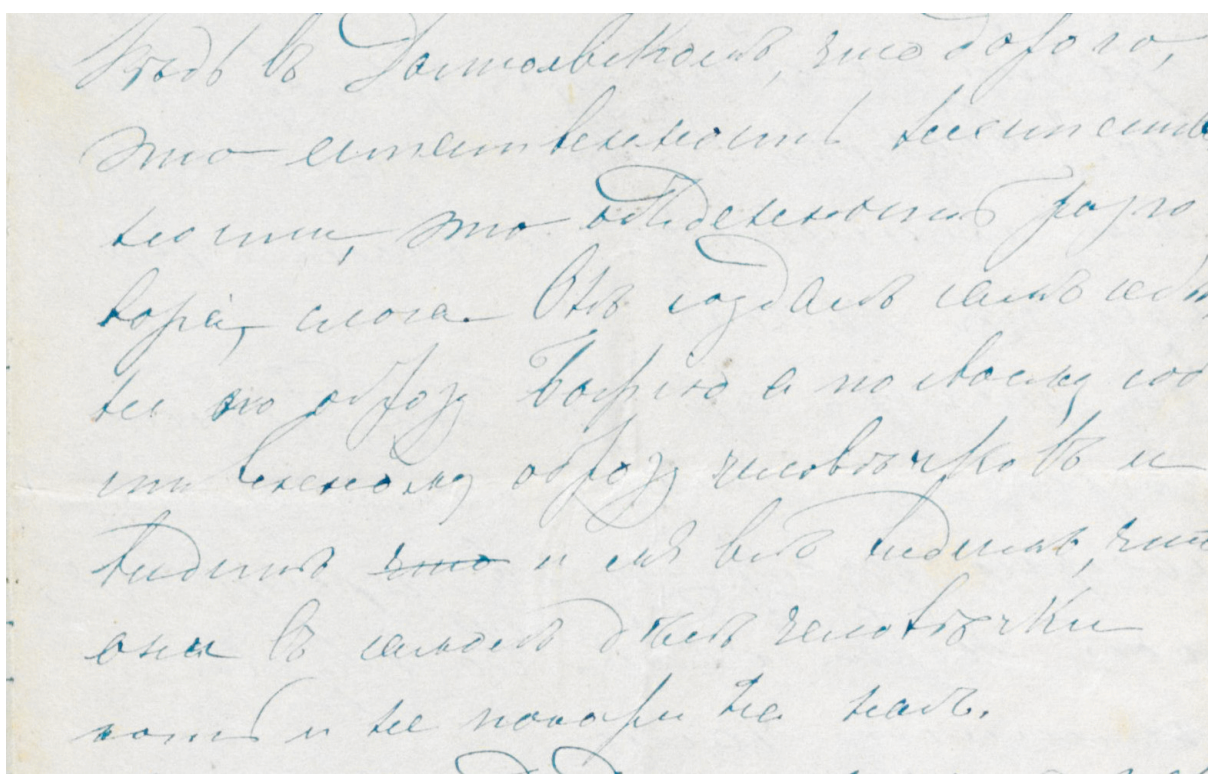

Илл. 1. Фрагмент письма Е. А. Штакеншнейдер к Я. П. Полонскому

Обзор печатных отзывов о романе «Униженные и оскорбленные» в 1861-1862 гг. позволяет заметить, что размышления двадцатипятилетней Е. А. Штакеншнейдер по глубине анализа ничуть не уступали профессиональной литературной критике.

Так, уже в январе 1861 г., после публикации первой части романа, автор «Московских ведомостей» А. Н. Плещеев писал лишь о выразительности и пронзительности («хватающие за сердце ноты») созданных Достоевским образов, а также о «фантастическом колорите», роднящем автора с Гофманом ${ }^{28}$. Н. Г. Чернышевский в январском номере «Современника» указывал только 
на «правдивость» повествования и выражал надежду, что публикующийся роман станет одним из лучших в отечественной литературе за «последние годы» ${ }^{29}$.

После выхода «Униженных и оскорбленных» все критики, решившие высказаться по поводу нового произведения, непременно давали оценку его образной системе, и мнения разделились. А. Хитров в журнале «Сын Отечества» отмечал реалистичность образов: «Герои романа - не какиенибудь бледные тени, но живые люди, говорящие каждый по своим убеждениям, согласно своему взгляду» ${ }^{30}$. Критик «Русского слова» $Г$. А. КушелевБезбородко, наоборот, утверждал, что Достоевский «не обрисовал, не очертил, не разъяснил ни одного живого лица, ни одного настоящего типа» ${ }^{31}$. Прозорливым, как и у Штакеншнейдер, оказался сентябрьский отзыв Н. А. Добролюбова (статья «Забитые люди»), в котором было указано на родство героев с автором, но при этом последнему отказывалось в мастерстве художника: «Эта бедность и неопределенность образов, эта необходимость повторять самого себя, это неуменье обработать каждый характер даже настолько, чтоб хоть сообщить ему соответственный способ внешнего выражения, - все это, обнаруживая, с одной стороны, недостаток разнообразия в запасе наблюдений автора, с другой стороны, прямо говорит против художественной полноты и цельности его созданий» ${ }^{32}$. В ноябре 1861 г. Е. Тур в «Русской речи» написала о романе как о произведении, не выдерживающем «ни малейшей художественной критики», образная система которого принималась с оговоркой: «...если б читателю можно было хоть на минуту не только помириться, но даже понять...» ${ }^{33}$. Последним в череде современных роману печатных отзывов стала разгромная статья E. Ф. Зарина «Небывалые люди». Ее заголовок не только полемично перекликался с названиями первого романа Достоевского «Бедные люди» и статьи Н. А. Добролюбова «Забитые люди», но и подразумевал буквальное прочтение слова «небывалый» как «несуществующий, немыслимый» по отношению к созданным Достоевским героям: «...люди эти <...> психологическиневозможные и потому никогда не бывалые люди» ${ }^{34}$. Желая доказать, что образы романа были созданы в «величайший ущерб правдоподобию», Е. Ф. Зарин ввел понятие «кукла» ${ }^{35}$, которым спустя три года воспользовался и сам Достоевский для характеристики «Униженных и оскорбленных» на страницах журнала «Эпоха». Комментируя письмо А. Григорьева, в котором речь шла о вынужденности фельетонной формы романа, он писал: «Совершенно сознаюсь, что в моем романе выставлено много кукол, а не людей, что в нем ходячие книжки, а не лица, принявшие художественную форму» (Д30; 20: 133-134).

Показательно, что «человечки» Е. А. Штакеншнейдер, хоть и имели сходство с «куклами» литературной критики в одном из своих значений («марионетки, послушные орудия»), но принципиально отличались от них как существа одушевленные и, следовательно, имеющие право на жизнь. Достоевский, позже назвавший «Униженных и оскорбленных» «произведением диким», 
все же отстаивал перед публикой художественную достоверность главных героев и любовался своим созданием, апеллируя именно к читательскому мнению:

«Но вот что я знал наверно, начиная тогда писать: 1) что хоть роман не удастся, но в нем будет поэзия, 2) что будет два-три места горячих и сильных, 3) что два наиболее серьезных характера будут изображены совершенно верно и даже художественно. <...> Вышло произведение дикое, но в нем есть с полсотни страниц, которыми я горжусь. Произведение это обратило, впрочем, на себя некоторое внимание публики» (Д30; 20: 134).

Нужно добавить, что к найденному образу мирка, в котором «человечки» живут по закону автора, Штакеншнейдер вернулась два десятилетия спустя, после личного знакомства с семьей писателя.

Приведенный выше фрагмент письма мемуаристки от 2 июля 1861 г., имеющий для отечественной читательской критики несомненную ценность, был в свое время изъят из контекста эпистолярного диалога и... оставлен без комментария ${ }^{36}$. А история отзыва имела продолжение.

Восхищенный литературной зоркостью своей корреспондентки, Полонский переписал ее мнение о романе и отправил Достоевскому, назвав Елену Андреевну «одной неизвестной ему (Достоевскому. - А. И.) петербуржской девушкой», что позволило уточнить дату знакомства Достоевского со Штакеншнейдерами: не ранее середины августа 1861 r. $^{37}$ Молоденькая «тетка» и не подозревала, чем обернутся для нее откровения с сотрудником редакции «Времени». Вот как она описывала произошедшее в письме от 8 августа 1861 г., сопровождая факты размышлением о происхождении «достоинства» своего слога:

«Что же касается моихъ писемъ, или слога, который Васъ удивиль, то и я удивлена: я не знала за ними никакихъ достоинствъ. Что же Вы препологали? Между тпомь къ похваламъ моего дяди я совспмг неравнодушна, и теперь твердо впрю въ ихъ достоинства, вирю слюпо. Вы бы хоть привезли какое нибудь изб нихб, хоть бымнг самой посмотрпоть, что въ нихъ. Вы знаете, письма Полонскаго надо у насъ читать вслухъ ${ }^{38}$, такъ узнали о моемъ отзывт о Достоевскихъ, и пристали ко мню, чтобы я его повторила, а я не помню, что такое написала, т. е. мнюніе то свое о романп знаю, еще бы я забыла своего мнпнія! Но повторить его удовлетворительно не могла, а думали, что я жеманюсь, не хочу сказать. - Яковъ Петровичь, мильй дядя, Васъ удивляетъ, что я не пишу хуже, меня удивляетъ, что я лучше не пишу: у меня столько словъ.

Вызнаете, что я много читала, но Выне знаете, сколько я думала, перечувствовала, сколько слушала и какъ мало говорила. Уменя было много привязанностей, но мало товарищей; я мало слушала, но мало говорила; я принимала много, но мало отдавала и носилась со своимь богатствомъ, и теперь ношусь, не зная, куда его дють. Когда я была моложе, я все думала, что непремпнно надо высказаться, теперь не думаю <...>. 
Конець “Униженныхъ" вышель тоже не нравится, вообще въ журналахъ ничего нитть хорошаго» ${ }^{39}$.

Днем раньше, 7 августа, видимо, не дожидаясь письма Штакеншнейдер, Полонский сам решился рассказать ей, как постарался сделать приятное Достоевскому, зная о его терзаниях по поводу последнего романа:

«Безъ всякаго умничанья скажу вамь тетка, что въ вашихъ письмахъ много умнаго - я вами доволенъ и языкъ у васъ такъ образовался, что - я - и не ожидаль - право не ожидаль! Всё такъ просто ясно и прозрачно - выраженья метки - нгтьг ни малюйшей растянутости - ну просто издавай я христоматію, помпстиль бъ туда и ваши письма - въ видю обращиковъ. - Говорю вамъ не шутя. - Ваше сужденье о Достоевскомь - право могло бъ занять место въ критикп. Я выписаль это сужденье (не называя васъ по имени) и послаль къ Фед. Достоевскому на прочтенье - прибавивъ отъ себя, что возможно ему будеть пріятно знать мнпнье о своемь романп - одной ему неизвпстной петербуржской дпвуишки ${ }^{40}$.

Так то тетка! Дядя гладить васъ за это по головкю - благо вы низенькая! —» ${ }^{41}$ (см. Илл. 2 и 3).



Илл. 2. Фрагмент письма Я. П. Полонского к Е. А. Штакеншнейдер от 7 августа 1861 г. 


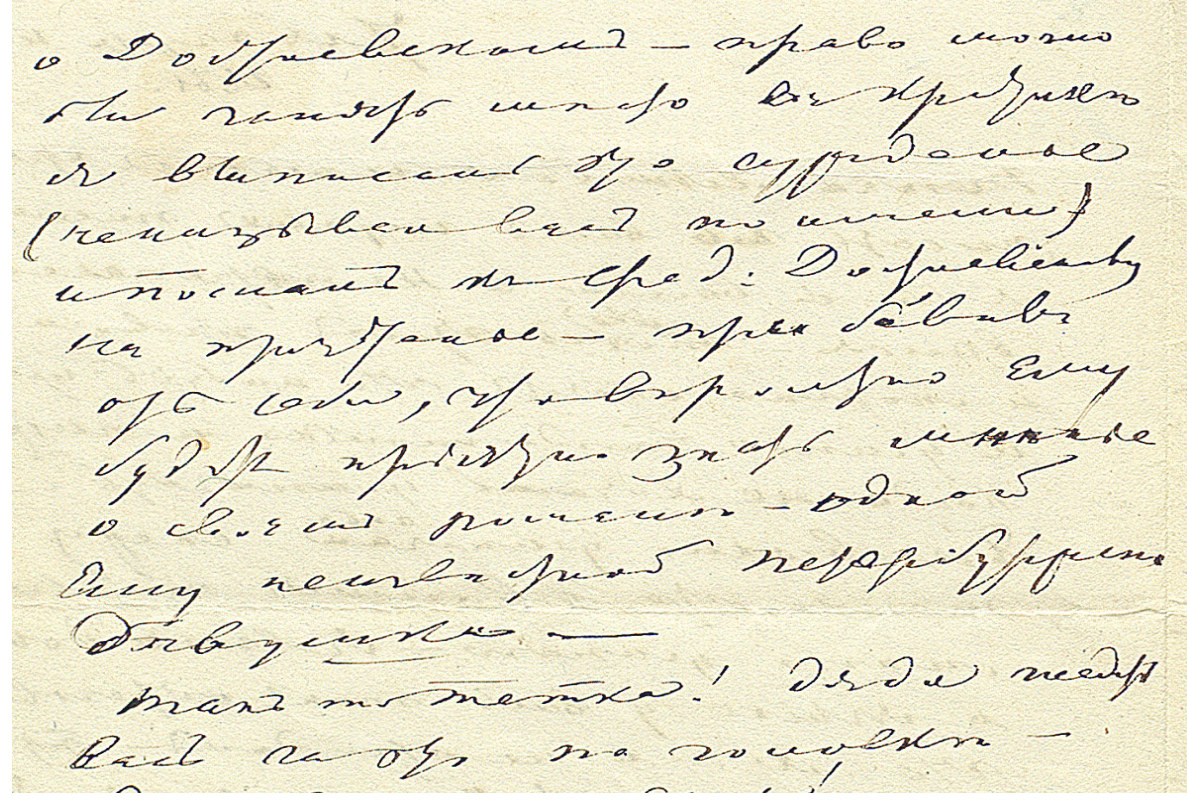

Илл. 3. Фрагмент письма Я. П. Полонскогок Е. А. Штакеншнейдер от 7 августа 1861 г.

Ответа на это письмо Полонского в архиве Е. А. Штакеншнейдер не сохранилось, зато осталось письмо Полонского от 21 августа 1861 г., в котором он, комментируя письмо Достоевского ${ }^{42}$, пишет об открытой неприязни реакционных изданий ко «Времени» и трактует их критику как желание отомстить ему за сотрудничество с Достоевскими:

«Достоевский мнгь пишеть что романъ мой встрпченъ маленькими поэтами не только холодно - иявно непріязненно - что Русс<кое > Слово надъ нимь глумится ${ }^{43}$ гадко и гнусно - ...Воть это меня интересуеть - что Вы мнг ничего объ этомь не пишете. - Я увпренг что и Краевскій ${ }^{44}$ и Катковъ ${ }^{45}$ будуть его ругать - это "Время" - у нихъ как бельмо на глазу - Русское слово дало бъ мнгь за этоть романь вдвое дороже чпмъ Достоевскій - и теперь ругаеть какъ вамъ это кажется!! -

Вы спрашиваете не пишу ли я свой романь - не пишу. Началь я его у себя за перегородкой - и продолжать буду за перегородкой же - на В<асильевскомъ> острови» ${ }^{46}$ (см. Илл. 4).

Известно, что роман в стихах так и не был дописан: Полонскому нужно было «слишком много условий для того, чтобы такое произведение в стихах могло в настоящее время приковать к себе внимание читающей публики» ${ }^{47}$. Однако Штакеншнейдер, со свойственной ей проницательностью, не только назвала главную причину творческой неудачи поэта, но и передала 
настроения читающей публики 1861-1862 гг., во многом объясняющие и неприятие критикой романа Достоевского:

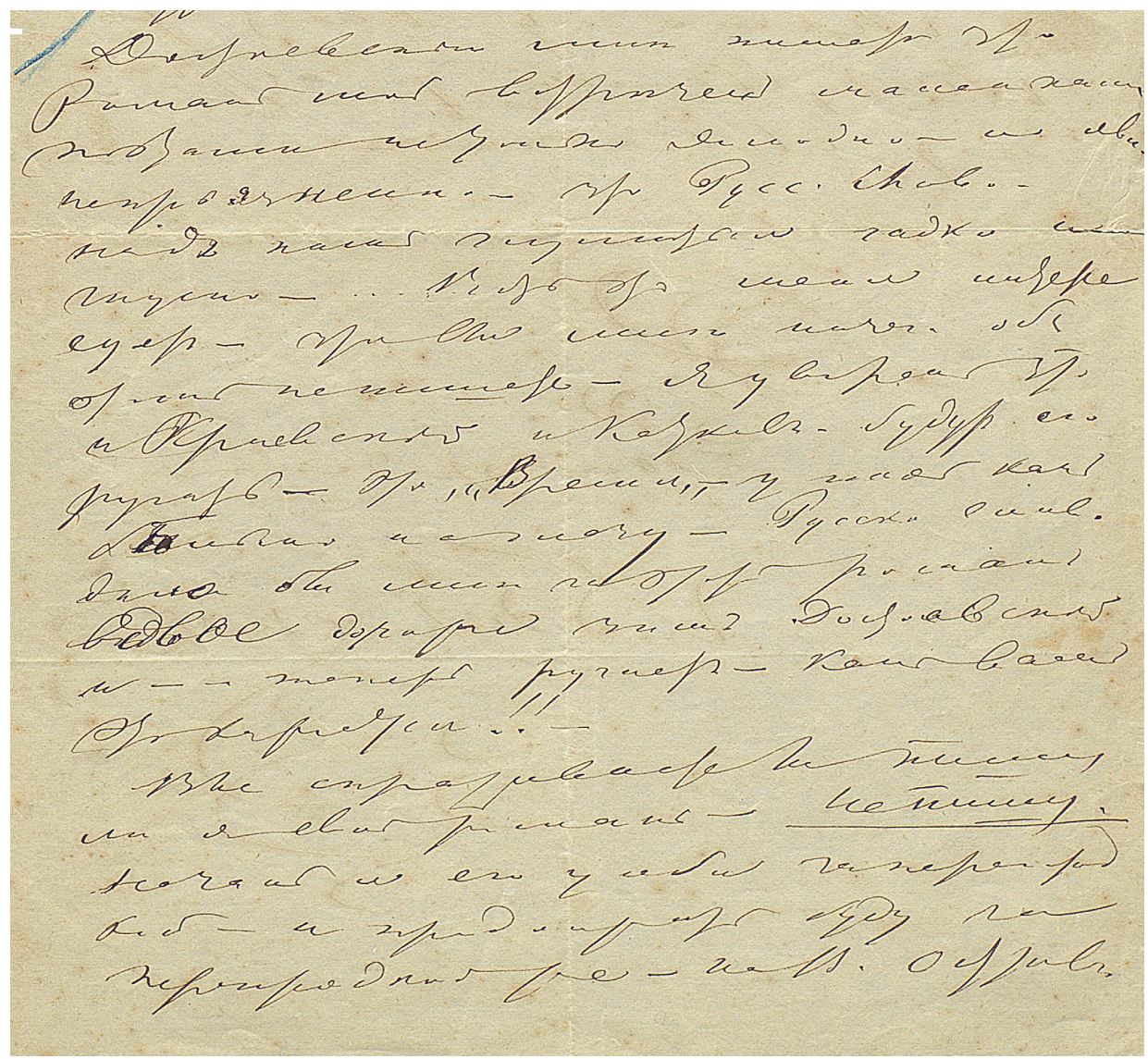

Илл. 4. Фрагмент письма Я. П. Полонского к Е. А. Штакеншнейдер от 21 августа 1861 г.

«Бедное “Свежее Преданье”, бедный Полонский, опоздавший. Не совсем приятно явиться прежде времени, но опоздать даже очень неприятно.

Всего здоровее то, что является в свое время, но, потом, уж лучше явиться прежде времени, чем опоздать. В преждевременном явлении есть молодые, хоть не развитые силь, есть задатки будущего, ну, их хоть и не разглядят, так они все же своей собственной силой крепки; а в опоздавших ничего нет. Какие в нем силь... Какие силь в свежем преданье... Силь таланта Полонского... Полонский не романист. Будь он романист, может быть, победил бы он и самую несвоевременность. Он этого сначала не разглядел. Полюбив свою мечту, он было оскорбился, что другие также не полюбят ее. 
- Дядя, - сказала я однажды, - вы говорите, что "Свежее Преданье" нашло мало сочувствия, а я удивляюсь, что оно столько начло его.

Подумайте вы сами, кого интересуют подобные вещи... Если вам нужно непременно сочувствие публики, бросьте писать. Если вы можете обойтись без него, пишите, но на сочувствие не рассчитываите, оно не может быть, оно не в порядке вещей и не будет". нится когда-нибудь, нынешний порядок не вечен, вы сами знаете. Что будет за ним неизвестно. Хотите понравиться, подите рубить прозу, впутайте в неё слова: свобода, рабство, прогресс, иели, гласность и т. д., их найти нетрудно, и вы будете оценены по достоинству сегодня же". - "Спасибо, тетка, - отвечает Полонский, - вы подкузьмили меня, теперь опять буду иметь волю написать две главы". В самом деле, поэты, подите рубить правду или ложитесь там и спите, пока не встанет ваша заря; может, она и никогда не встанет?» ${ }^{49}$.

Таким образом, согласно Штакеншнейдер, выходило, что, несмотря на «могиканство» Достоевского, написанный им роман вовсе не был «опоздавшим» (т. е. успевшим устареть, неактуальным), в отличие от романа Полонского, потому что истинное мастерство художника («романиста») проявляет себя, невзирая на «сочувствие публики» И «нынешний порядок» ее предпочтений.

История с отзывом о романе «Униженные и оскорбленные» не стала поводом для общения Е. А. Штакеншнейдер и Ф. М. Достоевского. Лишь по прошествии 12 лет, в 1873 г., возобновленное после многолетнего перерыва знакомство Достоевских и Штакеншнейдеров получило новое качество: теперь сама Елена Андреевна была хозяйкой и душой дома, и Достоевский с ней в последние годы жизни был рад общаться ${ }^{50}$. Подтверждением тому служат письма Штакеншнейдер Полонскому, в которых имя Достоевского продолжало упоминаться при самых разнообразных обстоятельствах:

7 марта 1877 г.:

«Грустная была зима, ты, Покровскій ${ }^{51}$, А. Н. Энгельгардть и наконець прихворнуль и Страховъ ${ }^{53}$. У Достоевскаго было въ короткое время три припадка, оттого и запоздаль Дневникъ ${ }^{54}{ }^{55}$.

20 июля 1880 г.:

«Как живешь? Мы живемг слава Богу и люто у насъ хорошее. Но я, скажу тебг по правдг, вспмъ временамъ года, предпочитаю осень и горжусь этимь вкусомъ моимб, потому что таковъ и у тебя, таковъ быль и у Пушкина. И такъ, я жду осени и свиданія со вспьи, кого не вижу теперь. Также, какъ и тебя, потеряла я Достоевскаго. Но съ нимъ мы условились переписываться, онъ не такой воръ, какъ ты; а между тпмъ не пишетъ. Можетъ быть письмо пропало или онъ упхаль въ Эмсъ ${ }^{56}$, а я писала въ Старую Руссу. И въ моей разлукп съ нимъ и Топоровъ ${ }^{57}$ помочь не можетъ» ${ }^{58}$. 
7 января 1881 г.:

«Милььй дядя!

Давнишнею мечтою Андрюши 59 было служить под начальствомь К. П. Побюдоносцева. Онъ объ этомб мечталь, когда ещзе служиль въ провиниіи и когда К. П. еще не быль оберпрокуроромъ Св. Синода.

Ньнпинюю ночь меня точно оспнило мыслью обратиться къ тебю и просить тебя замолвить слово за Андрюшу у П. <...>

Нам же съ тобой, мильй дядя, какъ поэту и женщинп законъ не писанъ; да я и не вижу ничего необычайнаго въ подобномь шагп <...> Сдплай это для твоей старой тетки. Я бы могла попросить и Достоевскаго, да хочу тебя» ${ }^{60}$.

Дружески почтительные отношения с Достоевским, бережно хранимые Штакеншнейдер почти десять лет, после смерти писателя получили новое выражение. Верная решению благодарить «за жизнь и ее дар» правдивым свидетельством и вдумчивым наблюдением Елена Андреевна (ей к тому времени было уже более 50 лет) не только поддержала вдову писателя ${ }^{61}$, но и занялась восстановлением фактов жизни Достоевского вплоть до деталей и мелочей, ей одной подмеченных.

Собранный материал был изложен на страницах дневника за 1884 г., рукопись которого до нас не дошла. Документ был частично опубликован в журнале «Голос минувшего» ${ }^{62}$, а позже искаженно воспроизведен в единственном издании сочинений Е. А. Штакеншнейдер как «набросок воспоминаний о Достоевском» ${ }^{63}$. Многие наблюдения мемуаристки поражают своей прозорливостью. Так, Штакеншнейдер принадлежит мысль о прямой связи образной системы произведений писателя с сословным - «мещанским» - типом мышления:

«Он знает все изгибы души человеческой, предвидит судьбы мира, а изящной красоты от пошлой не отличит. Оттого ему и не удаются женские лица, разве одни только мещанские. Многие, со страхом подходя к нему, не видят, как много в нем мещанского, не пошлого, нет, пошл он никогда не бывает, и пошлого в нем нет, но он мещанин. Да, мещанин. Не дворянин, не семинарист, не купец, не человек случайный, вроде художника или ученого, а именно мещанин. И вот этот мещанин - глубочайший мыслитель и гениальный писатель» [Штакеншнейдер: 438].

Именно Штакеншнейдер одна из первых высказалась о наставническом, объединяющем для людей русской культуры начале творчества Достоевского:

«Чем больше я думаю о Достоевском, тем больше убеждаюсь, что значение его среди современников вовсе не в литературном его таланте, а в учительстве» [Штакеншнейдер: 458]. 
Для иллюстрации своих обобщающе-универсальных выводов Елена Андреевна обращалась к анализу частностей. Например, она постаралась передать читательские ощущения от погружения в романную стихию Достоевского и воспользовалась найденным двадцать лет назад образом «человечков», которые теперь показательно эволюционировали в «людей»:

«Читая Достоевского, вы чувствуете себя точно прямо с утомительной дороги попавшим вдруг в незнакомую комнату, к незнакомым людям. Все эти люди толкутся вокруг вас, говорят, двигаются, рассказывают самые удивительные вещи, совершают при вас самые неожиданные действия. Слух ваш, зрение напряжены в высшей степени, но не глядеть и не слушать невозможно. До каждого из них вам есть дело, оторваться от них вы не в силах. Но они, все тут разом, каждый со своим делом; вы силитесь понять, что тут происходит, силитесь присмотреться, отличить одного от другого людей этих, и если при неимоверных усилиях поймаете, что каждый делает и говорит, то зачем они все тут столклись, как попали в эту сутолоку, — никогда не поймете; и хоть голова осилит и поймет суть в конце концов, то чувства все-таки изнемогут» [Штакеншнейдер: 459].

У Штакеншнейдер получалось, что необычайность и увлекательность повествования («рассказывают самые удивительные вещи, совершают при вас самые неожиданные действия») обладает удивительным свойством подчинять читательские чувства («слух ваш, зрение напряжены в высшей степени») и волю («оторваться от них вы не в силах») с целью постижения основной идеи произведения («голова осилит и поймет суть в конце концов») через сильное читательское сопереживание происходящему («чувства всетаки изнемогут»). Таким образом, Е. А. Штакеншнейдер отметила и катарсическое воздействие прозы Достоевского, достигающееся как содержани$\mathrm{eм}^{64}$, так и специфической художественной формой, осваивая которую читатель соглашался принять героев за «человечков», а не за «кукол».

Создавая в течение четверти века свой портрет знаменитого современника, Штакеншнейдер постепенно смещала ракурс от видимого и явного к невидимому, скрытому от поверхностного взгляда. Начав свои наблюдения с фиксации выступлений писателя и реакции на них петербургской публики, она постепенно расширяла их описанием внешности, привычек, манеры чтения и разговора. Существенным дополнением к образу писателя стала попытка критической оценки его произведений и выявление особенностей созданного им художественного мира.

Самым поздним по времени (1884-1885 гг.) стал для Штакеншнейдер опыт характеристики так называемого «внутреннего человека» ${ }^{65}$ Достоевского совокупности душевных способностей, качеств и сил, которая не только определяла аксиологию «человека внешнего», но и существенно влияла на отношения с другими людьми. По мнению мемуаристки, основным 
свойством Достоевского, снискавшим ему признание читателей и непонимание среди «собратий по литературе», стало отсутствие гордости:

«Он не вполне сознавал свою духовную силу, но не чувствовать ее не мог и не мог не видеть отражения ее на других, особливо в последние годы его жизни. А этого уже достаточно, чтобы много думать о себе. Между тем он много о себе не думал, иначе так виновато не заглядывал бы в глаза, наговорив дерзостей, и самые дерзости говорил бы иначе» [Штакеншнейдер: 456].

Это лично выстраданное и потому-то опознанное Еленой Андреевной в Достоевском умение души «нагнуться, умалиться и пройти в душу ближнего» [Штакеншнейдер: 459] проявлялось у писателя и в доверчивости к постороннему мнению о себе - об этом свидетельствует и фрагмент поздней переписки Штакеншнейдер с Полонским от 29 июня 1885 г.:

«Жаль, насъ обоихъ уже не будетъ на свптю, когда будущее поколюніе будеть чтить имя Полонскаго и съ удивленіемъ спрашивать, кто такой быль Максимъ Бтлинскій ${ }^{66}$, а не то я бь жестоко дразнила тебя и хвасталась своей проницательностью. Но вюдь это и есть одинъ изг признаковъ истиннаго дарованія, и очень печальныцй дя самихъ носителей этого дарованія, что они мало ипнять самихъ себя. Таковъ ты, таковъ быль Тургеневъ, когда такъ жгуче страдаль оть мнпнія о немъ публики, таковъ быль и Достоевскій, когда такъ восхищался и какъ бъ удивлялся своимь у нее успюхамъ. Не уньвають и не удивляются а всегда сыты сами собой одни Максимы Бплинскіе и имъ подобные» ${ }^{67}$.

Кропотливая многолетняя собирательская и мемуарная работа Е. А. Штакеншнейдер, данный ею глубокий анализ дарования Достоевского, в подтексте которого проступает христианская аксиология, позволяют сделать вывод о ней как об одной из первых - добровольных - исследовательниц творчества писателя. А личное знакомство и возможность общения со всеми литературными деятелями Петербурга 2-й половины XIX в. не только придают ее свидетельствам дополнительную ценность, но и заставляют пристальнее всмотреться в «лагерь» читателей-современников Достоевского. На примере Е. А.сШтакеншнейдер видно, как, вопреки недоброжелательным оценкам критики, неуклонно возрастало и количество сочувствующих его идеям людей, и желание сохранить образ и наследие великого соотечественника для потомков.

\section{Примечания}

* Исследование выполнено при финансовой поддержке РФФИ, проект «Ф. М. Достоевский в русской критике 1845-1881» № 18-012-90012.

1 Как писала Е. А. Штакеншнейдер, «за малыми исключениями, почти все собратия его по литературе его не любили» [Штакеншнейдер: 456].

2 Цит. по: [Андрианова: 245].

3 Дневник Е. А. Штакеншнейдер. 1861-1863 гг. // РГАЛИ. Ф. 923.2.3. 
4 В 20-х числах декабря 1859 г. Достоевский с семьей впервые приезжает в Петербург после каторги и ссылки.

5 Достоевский Ф. М. Полн. собр. соч.: в 30 т. Л.: Наука, 1972-1990. Т. 20. С. 133. Далее ссылки на это издание приводятся в тексте статьи с указанием тома (нижним индексом - полутома) и страницы в круглых скобках с использованием сокращения Д30.

6 Первое упоминание о работе над романом содержится в письме Ф. М. Достоевского к А. И. Шуберт от 3 мая 1860 г. (см.: Эпистолярное наследие Ф. М. Достоевского... URL: http:// philolog.petrsu.ru/fmdost/letters/shubert/kshubertai03051860.htm; см. также: Д30; 28. 9), а дата завершения романа - 9 июля 1861 г. - указана автором в журнальном варианте.

7 См. переписку с Ф. Н. Бергом (см.: Эпистолярное наследие Ф. М. Достоевского... URL: http:// philolog.petrsu.ru/fmdost/letters/bergfn/kBergu12071861.htm; см. также: Д30; 28, 17-18); а также: Достоевский. Материалы и исследования. Т. 5. 1983. С. 246-251, А. Н. Островским (см.: Эпистолярное наследие Ф. М. Достоевского... URL: http://philolog.petrsu.ru/fmdost/letters/ ostran/kostrovskomu24081861.htm; см. также: Д30; 28 : 23), Я. П. Полонским (см.: Эпистолярное наследие Ф. М. Достоевского... URL: http://philolog.petrsu.ru/fmdost/letters/polonsk/ kpolonskomu31071861.htm; см. также: Д30; 28, 19-21).

8 Из задуманных двадцати глав романа в стихах Я. П. Полонского «Свежее предание» во «Времени» было напечатано шесть: Время. 1861. Т. 3. № 6. Гл. І-ІІІ. С. 393-432; Т. 5. № 10. Отд. І. Гл. IV. С. 301-320; 1862. Т. 7. Гл. V-VI. С. 215-250.

9 Явления современной литературы, пропущенные нашей критикой // Время. 1861. Т. 2. Раздел «Критическое обозрение». С. 64. Статья с таким же названием атрибутируется Ф. М. Достоевскому (см.: Достоевский Ф. М. Полн. собр. соч.: в 18 т. М.: Воскресенье, 2005. Т. 5. С. 772).

10 Дружеское знакомство с семьей Штакеншнейдеров, и особенно с Е. А. Штакеншнейдер, поддерживалось Полонским до конца жизни. В частности, оно выразилось в шутливых обращениях «дядя» и «тетка», которыми обменивались адресаты в течение десятилетий. См. также: [Викторович], [Индзинская].

11 В январе 1860 г. у Полонского умер полугодовалый сын, а 8 июня того же года от тифа скончалась первая жена, Е. В. Устюжская (1840-1860).

12 Сохранилась обширная переписка Е. А. Штакеншнейдер и Я. П. Полонского: Письма Штакеншнейдер к Полонскому: Письма к Я. П. Полонскому. 1861-1897. 190 л. // РО ИРЛИ. Архив Я. П. Полонского. № 12612; Письмо к Я. П. Полонскому 1862. 7 апр. 2 л. // РО ИРЛИ. Р. III. Оп. 2. № 2001. Письма Я. П. Полонского к Е. А. Штакеншнейдер (21 апреля 1848 г. - 29 июня 1891 г.) // РГАЛИ. Ф. 923.2.9-923.2.11.

13 См. также: [Викторович], [Индзинская].

14 РГАЛИ. Ф. 923.2.10. Л. 2.

15 В дневнике 21 ноября 1860 г. Е. А. Штакеншнейдер записала: «Но ведь Достоевский еще больший мученик за ту же правду. (Уж будем все, за что они страдали, называть правдой, хотя я и не знаю хорошенько, за что они страдали, довольно того, что страдали.) Шевченко был только солдатом, Достоевский был в Сибири, на каторге. Между тем Шевченка ошеломили овациями, а Достоевскому хлопали много, но далеко не так. Вот и разбери». См. также запись от 11 января 1861 г. [Штакеншнейдер: 269, 281].

16 РГАЛИ. Ф. 923.2.10. Л. 8.

17 См.: Эпистолярное наследие Ф. М. Достоевского... URL: http://philolog.petrsu.ru/fmdost/letters/ polonsk/kpolonskomu31071861.htm; см. также: (Д30; 28 : 20).

18 Объявление о романе Полонского было сделано в майском номере журнала «Время» и носило ярко хвалебный характер: «В следующей, июньской книжке “Времени” мы печатаем одно из 
замечательнейших произведений нашей текущей литературы - первые три главы из романа в стихах Я. П. Полонского “Свежее преданье”. Мы говорим об этом произведении как о событии в литературе» (Д30; 19: 213).

19 Летом Штакеншнейдеры жили на даче (на мызе Ивановка) под Петербургом.

20 Неточная цитата стихотворения А. С. Пушкина «В альбом кнж. А. Д. Абамелек»: «И вашей славою и вами, как нянька старая, горжусь» (см.: Пушкин А. С. Полн. собр. соч.: в 10 т. Л.: Наука, 1977. Т. 3. С. 224).

21 Лето 1856 г. Е. А. Штакеншнейдер провела за границей с матерью, где вела подробный дневник.

22 Из домашних и салонных разговоров двадцатилетняя Е. А. Штакеншнейдер составила впечатление об Италии как об идеальном месте для занятий искусством. Нищета и грязь древних городов, а также бесстыдство, с каким итальянцы выпрашивали денег у иностранных путешественников, поразили девушку, и она констатировала ложность впечатления от Европы, прочно укоренившегося в России: «Карета въезжает в улицу, и вот, что есть грязных рук, все протягиваются к окнам кареты. Я сначала думала, что это мы спугиваем цыган кочующих, но оказалось, что это цивилизованные европейцы, коренные обитатели благодатной Италии. И об этом никто ни гу-гу! Напротив, все за границей превосходно, цивилизация и народы все цивилизованы, а у нас дико и народ дик» (РГАЛИ. Ф. 923.2.2. Л. 223 об. - 224).

23 Называя Достоевских «последними могиканами», Е. А. Штакеншнейдер, видимо, имела в виду верность редакции «Времени» (Федора и Михаила Достоевских) гуманистическим идеалам 1840-х гг., которые выразились в частности в глубокой внутренней связи романов «Бедные люди» (1844-1845) и «Униженные и оскорбленные» (1860-1861). Сама Штакеншнейдер, увлеченная либеральным подъемом 1860-х гг., в дневнике старалась запечатлеть последствия идейного обновления - отмену крепостного права, студенческие волнения и т. д. Так, 12 марта 1861 г. она записала: «Случилось то, что революция прошла по России, прошла такою, какой ее не ожидали, и по пути все перемешала» [Штакеншнейдер: 291].

24 РО ИРЛИ. Архив Я. П. Полонского. № 12612. Штакеншнейдер Елена Андреевна. Письма (93) Полонскому Якову Петровичу. Автографы. 1861-1897. Л. 4 об. - 5.

25 Там же. Л. 8 об. - 9. «Множественность самостоятельных и неслиянных голосов и сознаний, подлинная полифония полноценных голосов действительно является основною особенностью романов Достоевского» [Бахтин: 10].

27 «...Достоевскому же рассказчики и хроникеры были нужны, чтобы ввести самого себя в действие, максимально это действие объективировать, создать необходимое соучастие рассказчика в рассказываемом». См.: [Лихачев: 6]. Московские ведомости. 1861. 17 января. № 13.

29 Современник. 1861. № 1. С. 86.

30 Сын Отечества. 1861. № 9. С. 1094.

31 Русское слово. 1861. № 9. С. 46.

32 Современник. 1861. № 9. С. 114.

33 Русская речь. 1861. 5 нояб. № 89. С. 574-575.

$343<$ ари>н. Небывалые люди // Библиотека для чтения. 1862. № 1. С. 46.

35 «...На эту человеческую куклу, названную у нашего романиста Алешей Волконским». См.: 3<ари>н. Небывалые люди. С. 32-33. 
36 Достоевский. Материалы и исследования. Л.: Наука, 1983. Т. 5. С. 255; см. также: [Летопись...: 323-324].

37 По воспоминаниям Е. А. Штакеншнейдер, Достоевский бывал «почти каждую субботу, когда принимали мы внизу, т. е. до 1861 года, и в 1861 году, когда гостиная была уже наверху, в бывшей детской» [Штакеншнейдер: 454]. Однако о личном знакомстве, по-видимому, речь не шла. 11 марта 1862 г. в письме к Полонскому девушка просила достать для нее карточку Достоевского: «Увидите <...> кланяйтесь ему <...> и Достоевским; Ф. М. в особенности, и возьмите Вы у него для меня его карточку» (РО ИРЛИ. Архив Я. П. Полонского. № 12612. Л. 15 об.).

38 Многие письма Я. П. Полонского Е. А. Штакеншнейдер не датированы, они были вложены в послания к матери, Марии Федоровне Штакеншнейдер, с которой поэт состоял также в многолетней переписке. По правилам, заведенным в семье, у дочери не должно было быть никаких секретов от матери.

39 РО ИРЛИ. Архив Я. П. Полонского. № 12612. Л. 12 об. - 13 об., л. 7.

40 Письмо Я. П. Полонского к Ф. М. Достоевскому, о котором идет речь в письме первого к Е. А. Штакеншнейдер, не сохранилось.

41 РГАЛИ. Ф. 923.2.10. Л. 9 - 9 об.

42 Речь, вероятнее всего, идет о письме Достоевского Полонскому от 31 июля 1861 г. с характеристикой появившихся отзывов на «Свежее преданье»: «Въ литератург, какъ вы сами можете вообразить, отзывовъ еще нпть, кромп тпхт, которые не терпится, чтобъ не ругнуть. Партія Минаевыхъ, Курочкиныхъ (воображающихъ что они составляють партію) ругаются. <...> Но гадости вспхъ этихъ мозгляковъ разумпется не импють ни смысла, ни вліянія» (Эпистолярное наследие Ф. М. Достоевского... URL: http://philolog.petrsu.ru/ fmdost/letters/polonsk/kpolonskomu31071861.htm). Насмешку над произведением Полонского содержала одна из статей фельетонной серии Д. Д. Минаева «Дневник Темного человека» в журнале «Русское слово» (№ 7. С. 16-22).

43 В рукописи ошибочно: глумиться

44 А. А. Краевский в 1861 г. был редактором журнала «Отечественные записки».

45 Редакция «Времени» начала полемику с журналом М. Н. Каткова «Русский вестник» в № 3 (статьи «Образцы чистосердечия» и ““Свисток” и “Русский вестник”»), она была продолжена в № 5 и № 6 (статьи «Ответ “Русскому вестнику”», «Литературная истерика»).

46 РГАЛИ. Ф. 923.2.10. Л. 14.

47 Полонский Я. П. Свежее преданье. Роман в стихах. М.: Правда, 1986 [Электронный ресурс]. URL: http://az.lib.ru/p/polonskij_j_p/text_0070.shtml

48 [Штакеншнейдер: 309].

49 Вторая часть цитаты - ранее не публиковавшийся фрагмент рукописи: РГАЛИ. Ф. 923.2.3.

50 Взаимная симпатия и доверительность тона видна из переписки Ф. М. Достоевского и Е. А. Штакеншнейдер: «Я Вас люблю, — писал ей Достоевский 17 июля 1880 г., — и Вы это знаете» (Д30; 30: 198).

51 Покровский Михаил Павлович (1831-1893), был знаком с братьями Достоевскими со студенческих лет. Благодаря его участию возобновилось знакомство Достоевских со Штакеншнейдерами в 1873 г.

52 Энгельгардт Александр Николаевич (1832-1893) - посетитель литературно-художественного салона Штакешнейдеров. Достоевский был хорошо знаком с женой А. Н. Энгельгардта, Анной Николаевной Энгельгардт (1838-1903). Е. Штакеншнейдер упоминает ее в отдельном очерке «Из истории женского движения» [Штакеншнейдер: 417-422].

53 Страхов Николай Николаевич (1828-1896) - один из ведущих сотрудников журнала «Время». 

19 июня Достоевский отправил 17 июля 1880 г. В нем он просил извинения за задержку с ответом, объясняя ее крайней занятостью.

57 Топоров Александр Васильевич (1831-1887) - близкий знакомый И. С. Тургенева, а также Я. П. Полонского. юрист. Консультировал Достоевского во время написания романа «Братья Карамазовы». Позже был распорядителем одной из шести групп депутаций, участвующих в погребальном «Шествии за телом Достоевского» при перенесении его из квартиры в Александро-Невскую лавру (Новое время. 1881. № 1770. С. 1).

60 РО ИРЛИ. Архив Я. П. Полонского. № 12612. Л. 46-47.

61 А. Г. Достоевская вспоминала время после смерти мужа: «...а добрая Е. А. Штакеншнейдер так даже предлагала нанять две комнаты у сестры художника Айвазовского» [Достоевская: 446]. См. также: [Переписка Е. А. Штакеншнейдер...: 40-52].

62 Штакеншнейдер Е. А. Из воспоминаний о Ф. М. Достоевском (дневник 1884 г.) // Голос минувшего. 1916. № 2. С. 75-81.

63 Розанов Н. И. Е. А. Штакеншнейдер и ее дневник [Штакеншнейдер: 25].

64 О прижизненной полемике вокруг идеи очищения через страдание см.: [Захарова].

Разделение на «внешнего» (тело, плоть) и «внутреннего» (ум, сердце) человека было введено в христианскую антропологию ап. Павлом: «Посему мы не унываем; но если внешний наш человек и тлеет, то внутренний со дня на день обновляется» (2 Кор. 4:16).

66 Белинский Максим (наст. имя Иероним Иеронимович Ясинский, 1850-1931) - писатель, литературный критик.

67 РО ИРЛИ. Архив Я. П. Полонского. № 12612. Л. 63 - 63 об.

\section{Список литературы}

1. Андрианова И. С. «Нити, которые связуют нас»: Я. П. Полонский и Ф. М. Достоевский в архивных документах // Я. П. Полонский: личность, творчество, эпоха (посвящается 200-летию со дня рождения поэта). - Рязань, 2019. - С. 241-251.

2. Бахтин М. М. Собр. соч.: в 7 т. - М.: Русские словари, Языки славянской культуры, 2002. - T. 6. - $800 \mathrm{c}$.

3. Викторович В. А. Нефантастичность «фантастичного “Идиота”» // Неизвестный Достоевский. — 2018. — № 1. - С. 3-19 [Электронный ресурс]. — URL: http://unknown-dostoevsky. ru/files/redaktor_pdf/1524745042.pdf (15.07.2019). DOI: 10.15393/j10.art.2018.3401

4. Достоевская А. Г. Воспоминания. 1846-1917 / вступ. ст., подгот. текста, примеч. И. С. Андриановой и Б. Н. Тихомирова. - М.: ООО «БОСЛЕН», 2015. - 768 с.

5. Захарова О. В. Проблема катарсиса у Достоевского: из газетной полемики 1873 года // Проблемы исторической поэтики. — 2013. — № 8. - С. 219-229 [Электронный ресурс]. — URL: http://poetica.pro/files/redaktor_pdf/1431516511.pdf(15.07.2019). DOI: 10.15393/j9.art.2013.381

6. Индзинская А. В. «Вся ваша и с костылями Е. Штакеншнейдер»: переписка Е. А. Штакеншнейдер и А. Г. Достоевской // Неизвестный Достоевский. - 2015. — № 4. - С. 34-39 [Электронный ресурс]. - URL: http://unknown-dostoevsky.ru/files/redaktor_pdf/1455191625.pdf (15.07.2019). DOI: 10.15393/j10.art.2015.2505 
7. Летопись жизни и творчества Ф. М. Достоевского: в 3 т. - СПб.: Академический проект, 1999. - Т. 1. - 543 с.

8. Лихачев Д. С. В поисках выражения реального // Достоевский. Материалы и исследования. - Л.: Наука, 1974. - Т. 1. - С. 5-13.

9. Переписка Е. А. Штакеншнейдер и А. Г. Достоевской. 1878-1887 / подгот. текста и примеч. А. В. Индзинской и В. А. Викторовича // Неизвестный Достоевский. - 2015. № 4. - C. 40-52 [Электронный ресурс]. - URL: http://unknown-dostoevsky.ru/files/ redaktor_pdf/1453712629.pdf (15.07.2019). DOI: 10.15393/j10.art.2015.2508

10.К. П. Победоносцев и его корреспонденты. Письма и записки / с предисл. М. Н. Покровского. - М.; Пг.: Госиздат, 1923. - Т. 1: Novum regnum. Полутом 1. - 440 с.

11.Неизданные письма к Достоевскому / публ. А. И. Батюто, А. М. Березкина, Т. И. Орнатской, Г. В. Степановой, И. Д. Якубович // Достоевский. Материалы и исследования. - Л.: Наука, 1983. - Т. 5. - С. 246-270.

12. Штакеншнейдер Е. А. Дневник и записки (1854-1886) / ред., ст. и комм. Н. И. Розанова. - М.; Л.: ACADEMIA, 1934. - 584 с.

Anna V. Indzinskaya

The State University of Social Studies and Humanities (Kolomna, Russian Federation)

annain76@mail.ru

\section{Fedor Dostoevsky in the Correspondence of Elena Stackenschneider with Jakov Polonsky}

Acknowledgements. The reported study was funded by RFBR, project no. 18-012-90012.

Abstract. Elena Andreevna Stackenschneider (1836-1897), memoirist and hostess of the literary and art salon in St. Petersburg in the 1870s - early 1880s, was keeping records on F. M. Dostoevsky and his creative work for 25 years (1860-1885). She used to remark his public speeches, describe his appearance and habits, give a critical assessment of his writings, and tried to identify the features of his artistic world, never doubting the magnitude of his talent. The unpublished correspondence of Yakov Polonsky with Elena Stakenschneider, as well as previously unpublished fragments of the diaries of the latter, made it possible to clarify the facts of the biography of Fedor Dostoevsky and to enrich the collection of vital criticisms and evidence of his activities and creative work. Thanks to her meticulous and longstanding work in accumulating materials and keeping memoirs, her deep analysis of Dostoevsky's genius whose underlying message consists in Christian axiology, it is possible to consider this woman one of the first female researchers of the writer's creation. The example of E. A. Stackenschneider evidentiates how despite the negative criticism grew up the number of sympathizers of her ideas who aspired to keep the image and heritage of their great compatriot for the descendants.

Keywords: Elena Stackenschneider, Fedor Dostoevsky, Yakov Polonsky, correspondence, memoirs, literary criticism

About the author: Indzinskaya Anna V. - PhD in Philology, The State University of Social Studies and Humanities (ul. Zelenaya 30, Kolomna, Moscow region, 140411, Russian Federation) Received: September 12, 2019

Date of publication: December 6, 2019

For citation: Indzinskaya A. V. Fedor Dostoevsky in the Correspondence of Elena Stackenschneider with Jakov Polonsky. In: Neizvestnyy Dostoevskiy [The Unknown Dostoevsky], 2019, no. 4, pp. 139158. DOI: 10.15393/j10.art.2019.4341 (In Russ.) 


\section{References}

1. Andrianova I. S. “The Threads That Bind Us”: Yakov Polonsky and Fedor Dostoevsky in Archival Documents. In: Ya. P. Polonskiy: lichnost', tvorchestvo, epokha (posvyashchayetsa 200-letiyu so dnya rozhdeniya poeta) [Ya. Polonsky: Personality, Creativity, Epoch (a Tribute to the Poet's 200th Birthday Anniversary]. Ryazan, 2019, pp. 241-251. (In Russ.)

2. Bakhtin M. M. Sobranie sochineniy: $v$ tomakh [Collected Works: in 7 Vols]. Moscow, Russkie slovari, Yazyki slavyanskoy kul'tury Publ., 2002, vol. 6. 800 p. (In Russ.)

3. Viktorovich V. A. A Non-Fantastic Character of the «Fantastic Novel “The Idiot"». In: Neizvestnyy Dostoevskiy [The Unknown Dostoevsky], 2018, no. 1, pp. 3-19. Available at: http://unknown-dostoevsky.ru/files/redaktor_pdf/1524745042.pdf (accessed on July 15, 2019). DOI: 10.15393/j10.art.2018.3401 (In Russ.)

4. Dostoevskaya A. G. Vospominaniya. 1846-1917 [Memoirs. 1846-1917]. Moscow, Boslen Publ., 2015. 768 p. (In Russ.)

5. Zakharova O. V. The Concept of Catharsis in Fedor Dostoevsky's Works: From the Newspaper Polemics of 1873. In: Problemy istoricheskoy poetiki [The Problems of Historical Poetics], 2013, vol. 11, pp. 219-229. Available at: http://poetica.pro/files/redaktor_pdf/1431516511.pdf (accessed on July 15, 2019). DOI: 10.15393/j9.art.2013.381 (In Russ.)

6. Indzinskaya A. V. "All Sincerely Yours and with on Crutches, E. Stakenschneider”: E. A. Stakenschneider's Correspondence with A. G. Dostoevskaya. In: Neizvestnyy Dostoevskiy [The Unknown Dostoevsky], 2015, no. 4, pp. 34-39. Available at: http://unknown-dostoevsky.ru/files/ redaktor_pdf/1455191625.pdf (accessed on July 15, 2019). DOI: 10.15393/j10.art.2015.2505 (In Russ.)

7. Letopis'zhizni i tvorchestva F. M. Dostoevskogo: $v 3$ tomakh [The Chronicle of Dostoevsky's Life and Works: in 3 Vols]. St. Petersburg, Akademicheskiy proekt Publ., 1993-1995, vol. 1. 543 p. (In Russ.)

8. Likhachev D. S. In Search of the Expression of the Real. In: Dostoevskiy. Materialy $i$ issledovaniya [Dostoevsky. Materials and Researches]. Leningrad, Nauka Publ., 1974, vol. 1, pp. 5-13. (In Russ.)

9. Correspondence Between E. A. Stakenschneider and A. G. Dostoevskaya (1878-1887). In: Neizvestnyy Dostoevskiy [The Unknown Dostoevsky], 2015, no. 4, pp. 40-52. Available at: http:// unknown-dostoevsky.ru/files/redaktor_pdf/1453712629.pdf (accessed on July 15, 2019). DOI: 10.15393/j10.art.2015.2508 (In Russ.)

10.K. P. Pobedonostsev i ego korrespondenty. Pis'ma i zapiski [K. P. Pobedonostsev and His Correspondents. Letters and Notes]. Moscow, Petrograd, Gosizdat Publ., 1923, vol. 1, half volume 1. 440 p. (In Russ.)

11.Unpublished Letters to Dostoevsky. In: Dostoevskiy. Materialy i issledovaniya [Dostoevsky. Materials and Researches]. Leningrad, Nauka Publ., 1983, vol. 5, pp. 246-270. (In Russ.)

12. Stakenschneider E. A. Dnevnik i zapiski (1854-1886) [Diary and Notes (1854-1886)]. Moscow, Leningrad, Academia Publ., 1934. 584 p. (In Russ.) 